\title{
A Case of Spindle Cell Carcinoma of the Larynx
}

\author{
Kohei Nishida and Tetsu Takeo
}

\begin{abstract}
We report herein on a rare case of spindle cell carcinoma in the laryngeal arytenoids. A 60-year-old man presented at our hospital with dyspnea. We performed an emergency tracheostomy to maintain his airway. A biopsy led to the diagnosis of a low specialization type of malignant tumor such as a sarcoma. We performed a total laryngectomy. Postoperative pathologic examination revealed that the greater part of this tumor was composed of spindle-shaped atypical cells and squamous cell carcinoma at an advanced stage, pT3N0M0, so that the final diagnosis was spindle cell carcinoma. We performed postoperative therapy, radiation therapy and chemotherapy with doxorubicin and ifosfamide. Postoperatively the patient has been doing well for 18 months without any sign of recurrence or metastasis. There is as yet no established chemotherapy regimen, so we need to share our experiences regarding chemotherapy for spindle cell carcinomas.
\end{abstract}

Keywords : spindle cell carcinoma, radiation, chemotherapy, doxorubicin, ifosfamide

\section{References}

1) Barnes L, Eveson JW, Reichart P, et al. : Spindle cell carcinoma. World Health Organization Classification of Tumours. Pathology \& Genetics Head and Neck Tumours. pp 127-128, IARC Press, Lyon, 2005.

2) Ferlito A : Histological classification of larynx and hypopharynx cancers and their clinical implications. Pathologic aspects of 2052 malignant neoplasms diagnosed at the ORL Department of Padua University from 1966 to 1976. Acta Otolaryngol Suppl 342: 1-88, 1976.

3）鵜山太一, 井口広義, 山田 佳, 他: 下咽頭輪状後部から 発生した巨大紡鍾細胞癌の 1 例. 癌の臨 55: 147-151, 2009.

4) Viswanathan S, Rahman K, Pallavi S, et al. : Sarcomatoid (Spindle Cell) Carcinoma of the Head and Neck Mucosal Region: A Clinicopathologic Review of 103 Cases from a Tertiary Referral Cancer Centre. Head Neck Pathol 4: 265-275, 2010.

5) Olsen KD, Lewis JE and Suman VJ : Spindle cell carcinoma of the larynx and hypopharynx. Otolarygol Head Neck Surg 116: 47-52, 1997.

6）加藤久幸, 小森克彦, 櫻井一生, 他 : 喉頭紡鍾細胞癌の 1 症例. 喉頭 18: 39-43, 2006.
7) Miyahara H, Tsuruta $Y$, Yane K, et al. : Spindle cell carcinoma of the larynx. Auris Nasus Lrynx 31: 177-182, 2004.

8) Yoshimura E, Yuta A, Okawa C, et al. : Spindle cell carcinoma of the larynx treated by radiation therapy; a report of two cases. Pract Otol (Kyoto) 93: 967-970, 2000.

9）高橋正時, 木村百合香, 加藤智史, 他 : 中咽頭に発生した so-called carcinosarcomaの1例. JOHNS 24: 1771-1774, 2008.

10）武藤徹一郎：骨軟部肉腫 ADM/IFM. リスク別がん化学 療法レジメン改訂第 2 版（畠 清彦, 濱 敏弘, 平岡知子 編). 160-161 頁, 南江堂, 東京, 2008.

11) Thompson LD, Wieneke JA, Miettinen M, et al. : Spindle cell (sarcomatoid) carcinomas of the larynx: a clinicopathologic study of 187 cases. Am J Surg Pathol 26: 153-170, 2002.

12) Marioni G, Bottin R, Staffieri A, et al. : Spindle-cell tumours of the larynx: diagnostic pitfalls. A case report and review of the literature. Acta Otolaryngol 123: 86-90, 2003.

13) Benninger MS, Kraus D, Sebek B, et al. : Head and neck spindle cell carcinoma: an evaluation of current management. Cleve Clin J Med 59: 479-482, 1992.

14) Batsakis JG and Suarez P : Sarcomatoid carcinomas of the upper aerodigestive tracts. Adv Anat Pathol 7: 282-293, 2000. 


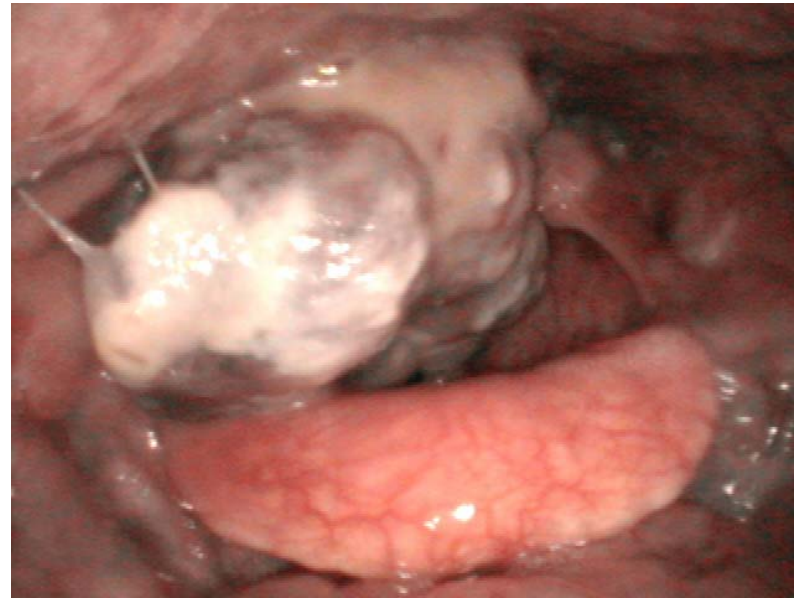

Cherry-red tumor with white coating occupaies the larynx.
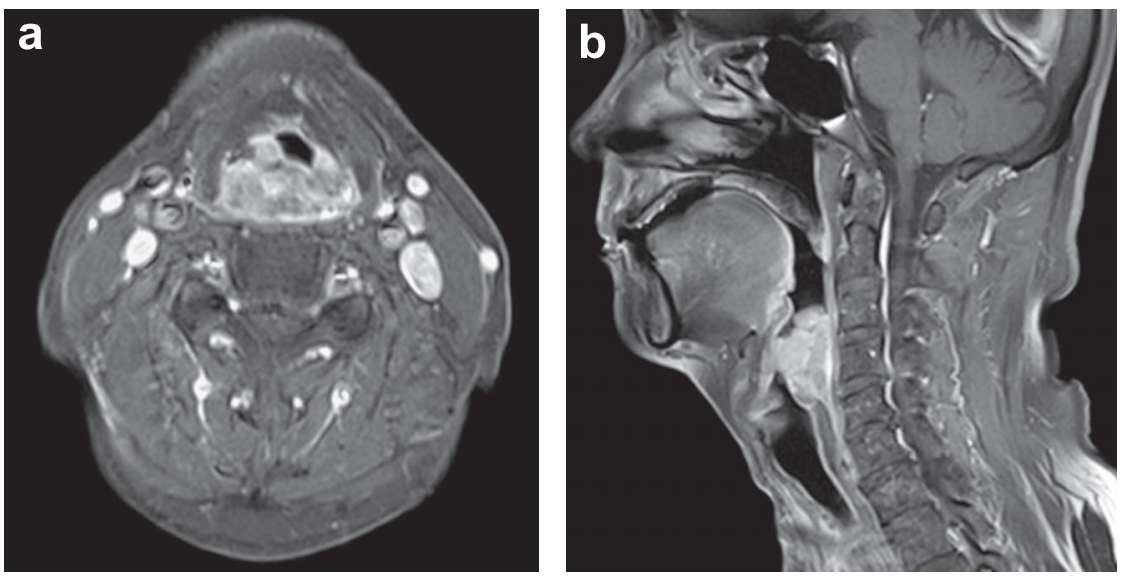

Gadolinium-enhanced T1-weighted MRI showing a heterogeneously enhanced tumor.
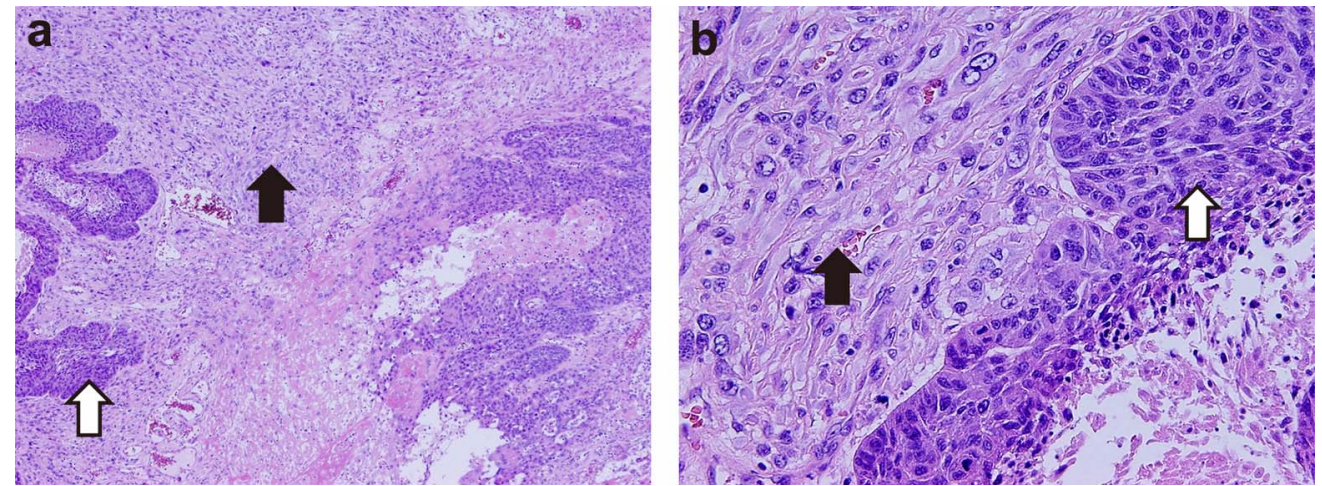

Histopathologic examination showing squamous cell carcinoma (white arrow) and spindle-shaped atypical cells (black arrow) (a: H\&E; low power, B: H\&E; high power). 